\title{
Analysis and Evaluation of an Environmental Management System: A Case Study at PT X-A Steel Company
}

\author{
Nadifa Dewinta Danastri \\ Department of Accounting, Faculty of Economics and Business \\ University of Indonesia \\ Indonesia \\ difadewinta26@gmail.com
}

\author{
Elvia R. Shauki \\ Department of Accounting, Faculty of Economics and Business \\ University of Indonesia \\ Indonesia \\ elvia.shauki@icloud.com
}

\begin{abstract}
This study aims to analyze and evaluate whether increased awareness regarding environmental issues has encouraged organizations to apply environmental management systems and use environmental management accounting (EMA), which drive environmental innovation, and thus enhance the company's environmental performance. There is, however, little evidence to consubstantiate this claim and thus this paper aims to investigate the issue. PT $X$ is one of the largest steel companies in Indonesia. This study highlights the importance of using EMA in implementing an environmental management system within the company. It shows that even though an environmental management system has been installed by the company to avoid any serious impacts of environmental pollution (e.g., in the form of iron dust), the company has yet to implement an EMA system with environmental management reporting (e.g., in the form of a cost-benefit analysis) to address problems. The company carried out its environmental management system to comply with the prevailing legislation and regulation, rather than as an environmental strategy and innovation for the future sustainability of the business.
\end{abstract}

Keywords-environmental management system, environmental strategy, environmental management accounting, environmental costs, environmental innovations, and environmental performance

\section{INTRODUCTION}

Environmental management is a systematic approach to environmental care in all aspects of a company's business operations, designed to realize environmental management in every aspect of a company's business that requires an environmental management system or what is often called an environmental management system (EMSyst) [1]. Ferreira [2] explains that EMSyst provides the organization's desire and consistency to redirect environmental concerns to resource allocation, responsibility sharing as well as ongoing evaluation of implementation, processes, and procedures.

The company's environmental management strategy (EMStrat) includes a reactive strategy that only aims to meet legal requirements. It also implements pollution controls and a proactive strategy [3]. Proactive environmental strategies require changes in routines, as well as proactive environmental operations and strategies. These elements have been identified as organizational competencies since they require complex coordination of some heterogeneous human and technical skills, along with resources, to reduce environmental impact while maintaining or enhancing the competitiveness of the enterprise (Christmann 2000; $[1,4]$ ).

Masanet-llodra [1] explains that environmental management accounting (EMA) is a system that combines physical environmental data and financial monetary data related to the environment. This EMA can be used as a tool in reporting environment-related activities, environmental cost efficiencies, and performance evaluations [2]. Environmental Accounting Guidelines Japan [5] says that environmental accounting is an effective way to accurately measure investments and costs associated with environmental conservation activities. Thus, the application of EMA is crucial for companies to detect and provide ways of treating waste to prevent environmental pollution.

By definition, innovation is a set of ideas or processes initiated by perceptions in the creation and improvement of products or services, processes, marketing and business practices, and these perceptions can be in a working environment or have a relationship with achieving success. Innovation is an essential element of all types and sizes of organizations. Companies that do not innovate environmentally will eventually experience decline and defeat, having lost competitive advantage against emerging companies or those that are constantly innovating and changing. To be able to know and assess whether a company has done environmental innovation, the company's environmental performance must be reviewed. It is a tangible form and a realization of the innovation undertaken and decided by every company.

This research is important to be able to assist companies in evaluating EMSyst that has been carried out within the company so as to maximize the reduction of air pollution around the factory area. The EMSyst system implemented so far in the company does not have a big impact in reducing air pollution that occurs. Furthermore, this research contributes by helping companies obtain information in the form of company evaluations of strategies, environmental cost components, benefits and also strategic environmental innovations in PT $X$ that may be used to improve the company's environmental performance in the future inorder to improve themselves and help companies maximize innovation. This research can help companies improve their image, too, mitigating the problem of iron dust waste that occurs, by helping companies know about their environmental performance so far. 
Prior research conducted on steel wire companies only focused on the process of managing the company's waste by managing environmental costs. This research focused on providing an overview and advice on alternative solutions through the role of the EMSyst in generating information, so that companies are able to identify costs, strategies, innovations and accounting management systems that are in line with the company's needs to optimize environmental performance, so as to reduce environmental damage.

PT $\mathrm{X}$ is a company engaged in the steelmaking industry. It has produced steel for various roads, buildings, factories, and other structures in Indonesia. PT X was established in 1970 , and its products include steel wire, steel rods, hotrolled sheet steel, and cold-rolled sheet steel. The results of this production generally become the raw materials for more advanced industry. The production process conducted by PT $\mathrm{X}$ was able to create B3 waste (hazardous and toxic materials), one of which is iron dust waste that can pile up, causing respiratory disturbances and damage to the surrounding environment.

Companies that engage in mining have a high risk of mining operations related to environmental and workplace accidents. The problem faced by PT $\mathrm{X}$ is its frequent environmental pollution incursions. Environmental problems such as air pollution, water pollution, and industrial solid waste are among the most frequent issues and challenges to overcome in Indonesia. Based on an initial interview with the chairman of the health, safety and environment division of PT $X$, it was disclosed that the environmental pollution occurred in PT X was due to lack of quality control conducted by the management company and also PT X has set an environmental cost investment for plant project development in accordance with the regulations and also the standards made by the Ministry of the Environment (Respondent 1, 2018). However, until 2018, environmental pollution, such as air pollution and iron dust waste was recorded.

Iron dust waste is thought to be the result of iron ore smelting process conducted by PT X [6]. Fakta Banten [7] reported again the occurrence of dust pollution from one of the joint venture companies owned by PT X. Residents complained of dust pollution that pollutes the air in residents' dwellings, this dust is believed to come from steel production waste [8]. Residents have reported this nuisance to the management of the company, and the company continues to seek its cause. Management of PT X strives to keep improving the quality control of the factory waste treatment plant in order to avoid the same pollution for the second time [7]. This stands in contrast to the awards earned by PT X for the environment; PT X in 2017 received the Blue PROPER Award from the Ministry of Environment for its success in preserving the environment and meeting all environmental requirements required by the government. This was conveyed directly during an interview by HSE manager, Mr. Afrizal, stating that by obtaining the Blue PROPER award by PT X the company's targeted environmental performance has been achieved and PT X has been proven to have carried out environmental management activities and also participated in preserving the environment around the company's industrial site. At the same time, iron dust waste is still repeatedly being found in the industrial area of PT X and until now the surrounding community continues to fall victim of the negligence of PT $\mathrm{X}$, which causes the air around the industrial site to be dirty.

Besides, other problems contained in PT $\mathrm{X}$ are in the recording of environmental costs incorporated into factory overhead costs and do not carry out recording and disclosure of environmental costs that occur specifically and solely (Respondent 1, 2018). The root of the problem that occurs in PT $X$ is the occurrence of air pollution repeatedly without solutions. This might be due to the fact that PT X has felt that the company has done the environmental management activities well and has complied with all existing laws and regulations; so that PT $X$ thinks that there are no more environmental problems in its industrial site. One way that companies can overcome these problems is to use a costbenefit analysis (CBA) based on the concept of EMSyst that has been described previously because the capital issued by PT X tailored to the analysis of costs and benefits incurred by the needs of the project undertaken. Thus, by using CBA, PT $X$ is expected to determine and measure the benefits of a project in the form of investment (cost) that does not exceed the capital issued or invested in reducing the occurrence of external failure costs in the future.

Based on the problems faced by PT X, the formulation of this research problem is as follows:

- What environmental strategies are applied to PT X?

- What is the role of environmental strategy with respect to the use of EMA and environmental innovation in PT X?

- What are the environmental cost components (financially and non-financially) recorded at PT X?

- What benefits (financial and non-financial) does PT $\mathrm{X}$ make after investing in these environmental costs?

- How does the environmental innovation done by the company affect the performance of environmental management at PT X?

\section{THEORETICAL REVIEW}

This section describes previous studies on EMSyst, the weaknesses and advantages of the EMSyst and the implementation of CBA in the company. In this section will also discuss the theoretical basis of the resource-based view theory.

\section{A. Environmental Management System (EMSyst)}

The environment has been a recent topic in the community since 2006 and, up until now, environmental issues are better-appreciated in the community and more people are concerned with the environment. Masanet-llodra [1] explains that environmental consciousness to some extent can be regarded as an emerging value in our society. The company tries to incorporate new values in these environment-related communities into its enterprise, through the merging of both new values in society and the environmental management system.

Khanna, et al. [9] explain that EMSyst can assist the company in the following ways:

- Minimize environmental responsibility;

- Maximize the efficient use of resources;

- Reduce waste; 
- Demonstrate an excellent corporate image;

- Building awareness of environmental concerns among employees;

- Gain a better understanding of the environmental impact of business activities; and

- Increase profit and environmental performance through more efficient operational processes.

EMSyst could be a powerful tool for companies to jointly improve their environmental performance and also improve their business efficiency. ISO 14001 has many potential benefits in addition to improving business performance but also can encourage the implementation of energy savings, waste reduction, low regulatory compliance costs and more efficient processes. Research conducted by Mezinska and Strode [10] in food sector companies find that the company successfully implemented EMSyst under ISO 14001 even though the environmental impact assessment of its production remains a challenging task due to the limited data available along the supply chain.

\section{B. Environmental Management Strategy (EMStrat)}

Khanna et al. [9] in his research explains that they change management practices and systems based on business implications of environmental issues, these strategies help change corporate culture and establish policies that should be able to integrate environmental issues into managerial decisions in all parts and levels of the organization. Government regulations or laws are usually treated as the most fundamental motive for the company's environmental problems [11]. Although, not all industries attract the same amount of government regulation $[12,13]$. Cater, et al. [14] found that 153 manufacturing companies adopted an environmental strategy as a reflection of their top management commitment, those environmental problems most often included in production and marketing strategies, followed by purchasing and personnel strategy, and there is a positive but very weak relationship between environmental strategy and firm performance.

\section{Environmental Management Accounting (EMA) and Environmental Management Reporting (EMR)}

De Beer and Friend [15] explain that EMA is part of environmental accounting and EMA has been claimed as a useful tool to overcome the limitations of conventional management accounting to better understand and facilitate measuring the problems related to the environment pertaining to the decision-making process. So, it can be concluded that EMA has a primary focus on providing information for decision-making within the internal discussions of the company.

Jasch [16] determined the important areas for implementing EMA within the company, namely:

- The assessment of annual environmental costs or expenditures,

- Product pricing,

- Budgeting,

- Investment appraisal, and

- Savings of environmental projects or setting quantified performance targets.
Judging from the important parts in the application of environmental management accounting, it can be concluded that the use of EMA in EMSyst is necessary to help facilitate management in viewing, monitoring and anticipating any possibilities that will or may occur. Besides EMA, there is an EMR that is equally important in realizing a good EMSyst, where companies serious about improving EMA will undoubtedly pay attention and also make improvements to environmental performance, controlling environmental costs. Duman et al. [17] explain that environmental problems may arise depending on future planned investment projects, wherein a solution plan derived from EMR should also be presented. In doing so, sufficient information may be presented to the public about events that may arise from nonfinancial environmental risks that can affect the business and its future, along with the financial position of the business.

\section{Environmental Management Innovation}

Cainelli, et al. [18] describe the importance of environmental innovations to achieve sustainable growth and-in some countries-policy makers consider environmental innovations as the basis for achieving sustainable growth patterns by incorporating environmental innovations into their policy agenda such as The Environmental Technologies Action Plan adopted by the European Commission in 2004 and The Europe 2020 Strategy. Environmental innovation is one of the important factors in EMSyst because they are needed in making EMStrat. EMStrat will be better if followed by further innovation and good environmental innovations that produce good environmental performance. Research conducted by Nadkarni and Narayanan [19] show empirical evidence that strategic and flexible environmental innovations affect business performance positively.

Figure 1 outlines the research framework for this study, it starts with the discussion on the strategy taken by the company which influences the company's reports, and the way the company invest in its program, product, process innovations which at the end will increase company's environmental performance.

\section{E. Environmental Management Performance}

Schultze and Trommer [20] explain that environmental performance is considered to be multidimensional construct that includes not only the environmental results and impacts of the company, its stakeholders, and the environment but also the principles of environmental responsibility and the environmental responses that determine future outcomes and impacts. Environmental performance is a measurable outcome of EMSyst, which deals with the control of its environmental aspects, and environmental performance assessment based on environmental policies, and environmental targets. Environmental performance is something that industry members can show by reporting their performance to the Ministry of the Environment for related programs. Research conducted by Moneva and Ortas [21] found a positive effect of environmental performance on financial performance.

\section{F. Resource Based View Theory}

Killen, et al. [22] explain that RBV is a strategic management theory widely used in project management, to test how resources can drive competitive advantage. Dunford, et al. [23] explain that RBV has also influenced 
strategic human resource management because human resources have an important value and function in a company. So, it can be concluded that the selection of RBV use in this study is intended because company $\mathrm{X}$ is in need of better strategic management that will be most effective in a project.

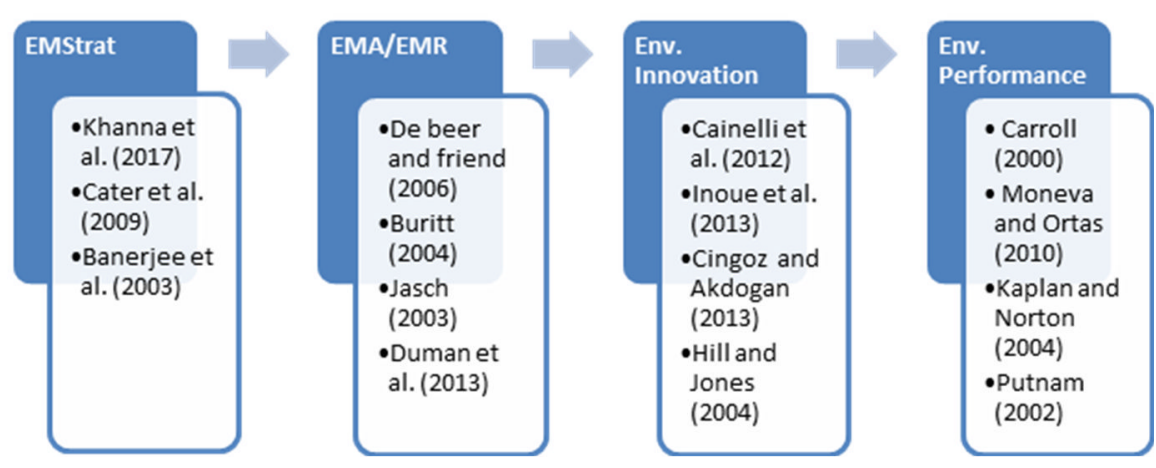

Fig. 1. Research framework

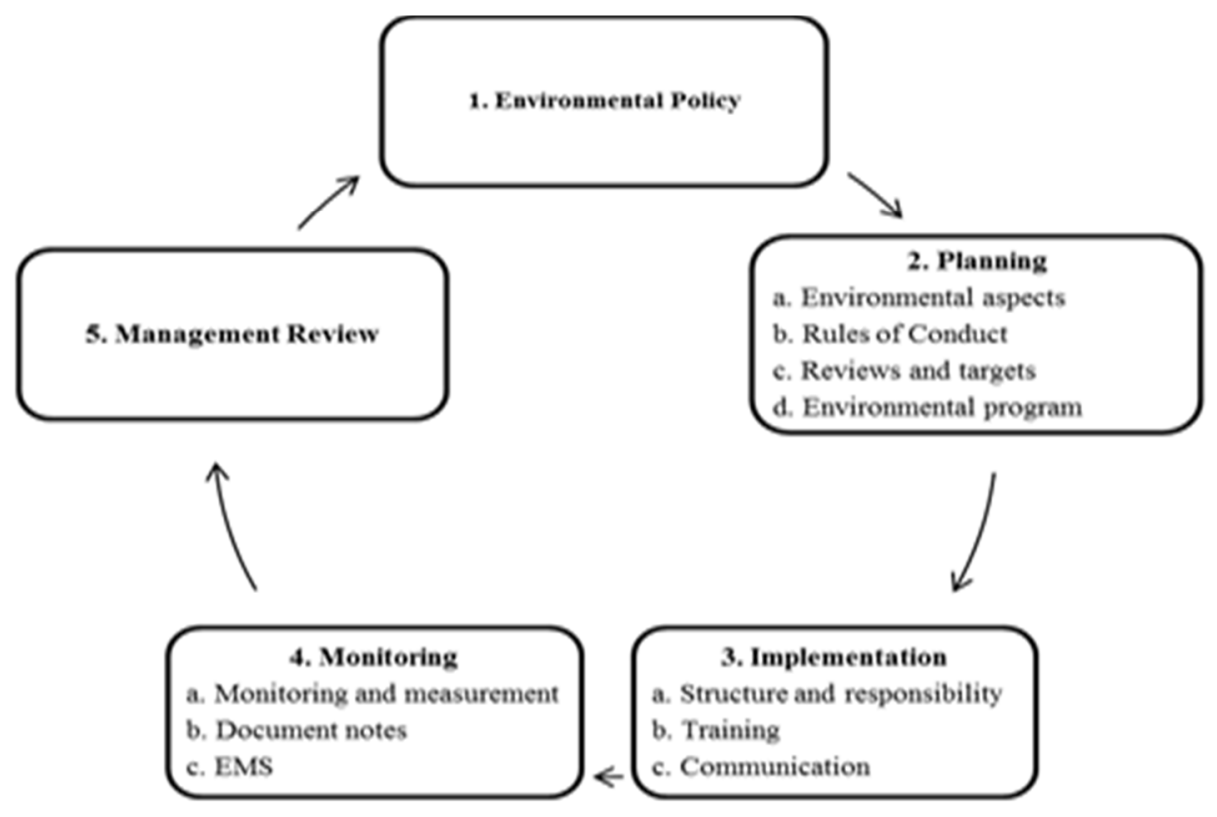

Fig. 2. Implementation of PT X Environment Management System

This situation occurs because most environmental performance and environmental costs in PT X are calculated and assessed based on each project undertaken.

\section{G. Research Framework}

The application of EMsyst with single case study method in one steel company in Indonesia (PT X) is backed by RBV theory, which is a strategic management theory that has direct validity. RBV theory emphasizes human resources in the company, too, where companies need to pay attention to human resources which are the important elements in carrying out and implementing a quality environmental management system so that the results obtained are as expected and there are also significant changes in the achievement of the company's environmental performance.
Because to create and design strategic management, quality human resources are needed who also have special knowledge and understanding of environmental management systems. Hence, the environmental management system is tailored in accordance with the needs of the company. And to identify the resources that can drive the company's competitive advantage through the implementation of EMStrat, EMA / EMR, environmental innovation as well as environmental performance.

\section{RESEARCH METHODOLOGY}

This research uses a qualitative approach and a single case study conducted on single unit analysis: PT X. The instrument of research in the form of interview and documentation. Field studies were conducted via in-depth 
interviews with competent resource persons in the field of environmental management and environmental accounting. Interviews were made using convenient sampling. Because such sampling is best used in observations of this study because of limited access and also the research permits given by the company to the location of the research and the data provided, namely the HSE and accounting division who know exactly about the environmental management system and environmental costs that exist in PT X. Interviews were conducted with two divisions that directly addressed the environmental costs of PT X namely the HSE division to get more accurate data and also to obtain more detailed information on the company's environmental issues, strategies, and innovations. To obtain a comprehensive and objective description of the phenomenon studied, the authors conducted in-depth interviews with various related parties as follows: manager of HSE, manager of accounting, senior engineer for environmental management systems, senior manager for accounting, HSE staff and also local communities. A literature review was undertaken by studying a number of studies, journals, books, articles, and other research results to obtain the theoretical framework that form the foundation in this study. In addition, literature study was also done by studying the provisions/regulations related to environmental factors in Indonesia regarding strategy, innovation, cost and management system. Documents used by researchers here in the process of documentation in the form of company profile, organizational structure, as well as systems and activities related to the environment. Data analysis was performed per division according to the data collected during the interview. The data was then processed by using descriptive analysis and content analysis.

\section{RESULTS AND DisCUSSION}

\section{A. Document}

Figure 2 shows the implementation of the environmental management system used by PT X. Environmental Policy is the prevailing laws and regulations made by the government, local government and other relevant bodies to be complied with by the company. PT $\mathrm{X}$ first collects and identifies existing environmental policies to guide the company, then it implements EMSyst through the planning stages of an environmental strategy (EMStrat) that addresses environmental issues, provisions of existing regulations, targets and creates an environmental program that suits the needs and responsibilities of the company.

After doing the planning, PT X created an organizational structure that would undertake and conduct all environmental management activities within the HSE division as well as describe the duties and responsibilities of each employee to clearly understand authority, rights and obligations about what it does, so that operational activities run well and are controlled. Then the HSE division conducted related training to implement the EMSyst within the company. And it can innovate such that employees can follow all the progress and changes regarding the rules, systems and also the application of the environment. Further monitoring communications between managers, staff, engineering, and technicians to control EMSyst both in the field and in the office to run in a conducive manner.

During the next stage, the HSE division is responsible for monitoring and measuring the machines, tools and also the main factors of pollution by the existing SOP. The senior manager of environmental management is responsible for recording documents on the results of monitoring and measurement conducted by the HSE division. The findings are then reported to the HSE manager for review, noting whether the process is in line with the existing SOP. To be able to implement what is shown in Figure 2 optimally, the management of PT X needs to do all the stages well, starting from planning of the environment strategy, implementing the environmental strategy, formulating environmental innovation to solve environmental problems, and producing the maximum environmental performance. A detailed description of the steps follows.

PT X has organized some environmental strategies in the company to be able to continue to compete in business. There are two main environmental strategies in PT X: (1) sell the waste generated by the factory directly while still in the production process and (2) manage the waste from the steel produced into products that have value added.

The environmental strategy created by PT X must then be carried out. Its implementation was much to cause environmental problems such as the existence of waste leaks. This oversight was due to the weaknesses and shortcomings concerning implementation of such good environmental strategies. Because the strategy created by PT X did not use EMA and EMR regarding calculation and recording, many weaknesses still occur in the environmental strategy created by PT X. This weakness suggests that PT X must act quickly so that the problem is not increasingly widespread and detrimental to the company through environmental innovation. Such innovations are often conducted by PT X, but two major innovations already done stand out: conducting quality analysis and analysis of waste management components.

This environmental management performance is the result of PT X's process from the planning of an environmental strategy created to achieve the company's target. In 2017, PT $X$ received several awards in the environmental field including one where PT X was awarded the Level 5 Green Industry Award from the Ministry of Industry of Indonesia. PT X also received the Blue Proper Award from the Ministry of Environment and Forestry of the Republic of Indonesia. Too, PT X made measurements in the implementation of environmental management in general, consistently implementing ISO 14001: 2015.

Through the awards received, the management of PT X wanted to show and prove that the company has succeeded in doing a conscientious job of environmental sustainability. PT $\mathrm{X}$ Thus sought to convince stakeholders and investors that PT $X$ continues to strive to maintain environmental sustainability by continuing to maximize all activities that can improve the company's future environmental performance.

\section{B. Discussion}

1) Environmental Strategy Performed by $P T \quad X$ (Environmental Management Strategy - EMStrat)

According to the findings presented in subsection 4.1, PT $\mathrm{X}$ has established a long-term strategy and has also implemented it. In the long-term plan, PT X aims to be able to sell the recycled industrial waste and value added to some neighboring countries as well as companies in Indonesia to 
earn additional revenue. PT $\mathrm{X}$ is still in the planning stage, calculating and observing its waste-recycling strategy (Respondent 1, 2018). Parameters emphasized in the achievement of environmental conservation and the existing ecosystem were achieved by complying with the existing legislation, making it difficult to transform PT $\mathrm{X}$ into a company green company as its slogan suggests.

Companies that want to transform themselves into green companies must have environmental insight and must control the utilization of natural resources wisely and sustainably to be able to ensure the needs of present and future generations. While all this time PT X has not implemented and done so, the insight about the importance of environmental and natural resources owned is still very low and has yet to lead to a green industry that is environmentally friendly as presented in its slogan (Respondent 2, 2018).

PT $\mathrm{X}$ also executes other environmental strategies by conducting a cleaner production program. This cleaner production program continuously adopts environmental conservation elements listed in SOP as well as its quality objectives. All these tools are integrated into ISO 14001 EMSyst and have been done consistently by the company since 1970 (Respondent 2, 2018). This affirmation is in line with what is explained by Masanet-Llodra [1] that ISO 14001 is a voluntary environmental initiative in which the guidance of the use of ISO can be a new challenge for companies to start handling environmental management in addition to acting economically.

PT X complements its environmental strategy by ensuring that its air pollution control facilities can work with full capacity in every production process to minimize exhaust gas or air emissions (Respondent 3, 2018). For example, waste heat is treated by using heat exhaust gas to reduce carbon emissions produced, which is one of the factors causing global warming. This strategy has been handled by the HSE division. This finding is consistent with that described by Khanna, et al. [9] that EMSyst can assist companies in maximizing the use of natural resources more efficiently and also reducing the waste generated.

Not only must natural resources be considered by PT X in forming its environmental strategy, but human resources that become the main element in the decision making, too, with respect to system, strategy, innovation and cost calculations done. Moreover, PT X still does not have personnel who understand about environmental aspects and things that support it in optimizing environmental performance well. Where employees in the HSE division do not have much knowledge and understanding of the importance of using EMA and EMR in implementing EMSysts owned by companies (Respondent 1, 2018).

This limitation is in accordance with the report submitted by the HSE manager, stating that PT X has not included the criteria for the acceptance of new employees of PT X with criteria that comprehend environmental issues in the management system, calculation, or environmental audit (Respondent 1, 2018). This is not in accordance with the previous research conducted by Dunford, et al. [23] that strategic management is influenced by the existence of human resources that have value and important functions in the company to optimize the company's competitive advantage. PT X needs to focus more on internal factors of the company i.e., human resources, in project management than it does.

\section{2) Role of Environmental Strategy with use of EMA and} Environmental Innovation in PT X

PT $X$ has yet to use EMA and EMR in any environmental strategy decision making (Respondent 1, 2018). PT X has not applied or planned the use of EMA in the planning and decision-making process about strategy and environmental innovation. PT X has not seen any urgency to place EMA in the company. As stated by Respondent 2 (2018), environmental strategy that has been done conformed to government regulation and legislation as the basis for decision-making is enough in overcoming the problem of environmental control. Although there are still many shortcomings and weaknesses in this regard, the company's management that solves the environmental problems of the HSE division feels it is sufficient in tackling the environmental issues that occur (Respondent 2, 2018).

A weakness lies in the fact that government regulations and legislation have not yet mandated the use of EMA and EMR in the sustainability aspect of the company's business. PT X turns government regulations and legislation into the basis for decision-making about systems on environmental strategies and innovations yet to be undertaken. Hence, it still has many weaknesses and is hardly optimal in its environmental strategies and innovations generated to resolve environmental problems. This outcome is because the existing legislation and regulations have been made during the past five to ten years. So, there are still many loopholes in the rules and laws, which permits PT X to have many shortcomings and weaknesses in the strategy and environmental innovation programs.

Environmental strategy conducted by PT $\mathrm{X}$ is called a clean production program, and yet even as a green company is still not following what has happened in the field. The cleaner production program has not been done optimally as there are still shortcomings in its implementation, i.e., planned eco-friendly activities, also the steel production process by PT X that is far from environmentally friendly, as every process that occurs in it produces waste products that are harmful to the environment and health. Besides, the program is not supported by planning by considering separate costing. Indeed, recording and financial reporting make it difficult for management to identify environmental costs in implementing their cleaner program (Respondent 1 , 2018).

PT X does not currently have a division or special team to create or implement EMA in the company due to the limited authority of each division to enter and supervise other divisions as well as separate the recorded fees of each division (Respondent 2, 2018). Managers are not even aware the meaning of EMA itself so to implement its use in their environmental strategy, making environmental innovation difficult to do. The importance of EMA in optimizing the role of environmental strategy in PT X seems to be far away to be realized due to the lack of knowledge of company management regarding EMA and its usefulness.

The lack of authority of the HSE division to assist existing factories in identifying, grouping, calculating and also recording environmental costs is also one cause of the inability to apply EMA in the company. Accordingly, the firm has not been able to write a report detailing all 
components and activities related to environmental costs in its annual financial statements. Nevertheless, the management of PT X considers that the strategies and environmental innovations undertaken so far are sufficient to prevent, avoid and even resolve all problems related to the environment.
Their attitude shows that their plan is not in accordance with what has been described by Duman, et al. [17], that to mitigate environmental problems arising from investing in a project, the company needs to develop a solution plan using EMR so that the information presented to the public is sufficient to inform it about events that may arise as well as non-financial risks that may affect the business at future.

TABLE I. PT X ENVIRONMENTAL COST FOR THE YEAR 2017

\begin{tabular}{|c|c|c|}
\hline Environmental Management A civities & \multicolumn{2}{|c|}{ Amount (in Kupiah) } \\
\hline Environmental care and presevvation & Rp & $1,172,665,245$ \\
\hline Environmental testing and monitoring & Rp & $244,734,000$ \\
\hline Setup and Waste management & Kp & $3,414,702,512$ \\
\hline I3 waste disposal & Rp & $250,000,000$ \\
\hline By waste TDS prepantion & Rp & $9,658,000,000$ \\
\hline Total & kp & $10,740,101,757$ \\
\hline
\end{tabular}

Source PT X Financial Report 2017

TABLE II. PT X ENVIRONMENT COST DETAILS FOR THE YEAR 2017

\begin{tabular}{|c|c|}
\hline Cost Type & Amount \\
\hline \multicolumn{2}{|l|}{ Environmental care and preservation } \\
\hline The cost of road maintenance and repair & Rp $\quad 717.963 .564$ \\
\hline The cost of arranging and maintaining the park & RP 250.717 .456 \\
\hline House Keeping Fee (Dee 2016-Juty 2017 ) & 12p 1.4 .42 .013 .005 \\
\hline House Keeping Non Plant service fee & RP $\quad 171.280 .322$ \\
\hline The cost of reforestation & 84.866 .561 \\
\hline Channel repair costs & 12p 05.468 .250 \\
\hline Channel cleaning costs & 12.042 .055 \\
\hline The east of mowing & 21.006 .453 \\
\hline House Keeping services Fee & RP $110,000,000$ \\
\hline Total cost of environmental care and conservation & 12 p $1,172,665,245$ \\
\hline Environmental testing and monitonng & kp $244,734,000$ \\
\hline Setup and Waste management & $12 \mathrm{p} 3,414,702,512$ \\
\hline B3 waste disposal & Rp $250,000,000$ \\
\hline 133 waste Tys prepamtion & 12p 5,058,000,000 \\
\hline Total & Rp $9.567,4,36.512$ \\
\hline Total Overall Environmental Cost & Rp 10.740,101.757 \\
\hline
\end{tabular}

Source Secondary Data, Year 2017

\section{3) Environmental Cost Component of PT X}

Environmental costs include all costs related to environmental damage and protection. They include contaminated sites, waste control technologies, and waste disposal. The details of the cost of the environmental components of PT X are not in accordance with those based on IFAC [24] because PT X has not included material costs of product outputs and material costs of non-product outputs in the cost component of its environmental management. The data in Table 1 shows that the environmental costs incurred by PT $X$ in 2017 amounted to Rp10 740,101,757. This amount is only $0.0007 \%$ of total cost of revenues amounting to USD1.08041 billion issued in 2017. The value is very small compared with the total revenue of the principal so that the environmental cost does not describe all activities undertaken by the company during a year. For fiscal year 2017, PT X split environmental management costs into five different components and PT X still uses the traditional recording system in recording these environmental management fees, wherein these costs are based only on reports from the health, safety and environment division alone, without covering environmental costs occurring in other divisions and factories. What follows are PT X's environmental costs for fiscal year 2017.

Table 2 shows the details of the process of calculating the five environmental cost components through two cost centers in the HSE division. Costs pertaining to those components are incurred following the activities performed off-budget 
made in 2016 as the cost of environmental management has only emerged since 2017. Based on the result of the documentation process obtained through HSE division of PT $\mathrm{X}$, it was ascertained that the environmental cost component within PT $X$ is still separated between accounts. PT X has not yet created a system that categorizes all environmental costs incurred by each division and the factory itself in PT X. The authority of the HSE division is limited to standard quality control following government regulation, but the HSE division is not included in the process operated by every steelmaking factory. So, the HSE division cannot know whether the environmental management activities undertaken by each division and factory have been maximized and are following existing SOP.

The company has yet to perform EMR in the calculation or budgeting of the environmental costs performed; it is clear there is no separate account in the annual financial statements of 2017 about EMA, so it is difficult to know the amount of total environmental costs incurred in real terms by the company.

\section{4) Benefits Generated After Investing in Environmental} Costs

After investing in the environmental cost component, PT $X$ then identified what benefits it derives from the investments made. The primary investments made by PT X so far are in machinery as well as waste treatment tools in production (Respondent 1, 2018). Benefits obtained by PT X range from financial to the non-financial. From the financial side, PT X does not incur any costs due to environmental pollution due to regular monitoring and prevention activities by the company (Respondent 1, 2018). Hence, the company benefits from lack of pressure or protests coming from the surrounding community with regard to the occurrence of environmental pollution (Respondent 1, 2018). These nonfinancial benefits cannot be described in monetary terms so they cannot be seen financially whether the investments made on environmental costs have a much greater benefit than the costs incurred. But the management of PT X believes that the benefits received by the company from investments issued in environmental activities are still far more significant than the budgeted costs for environmental components following the CBA calculations conducted by the company in calculating the environmental cost-benefit of invested capital (Respondent 2, 2018). This result is inconsistent with Anderson (2005) that the CBA can analyze the various activities that produce results for the environment and health. Because CBA cannot be used on a larger scale, PT X has only been able to find out how many financial benefits it has obtained through environmental investment activities. Yet PT X cannot identify the nonfinancial benefits that the company receives (Respondent 1, 2018).

Over the past five years, PT X noted that the company has never incurred any costs due to environmental pollution (Respondent 2, 2018). The cost is only limited to the cost of control and environmental management alone. If there is a leakage problem on machinery that generates dirty air, it is a common occurrence and should not be questioned, because it can still be handled by management well and has not caused widespread, harmful damage to the environment (Respondent 2, 2018). This notion represents a the problem in the community because PT X has been assuming that it has not harmed citizens by environmental pollution, even though air pollution has repeatedly happened.
5) The Influence of Environmental Innovation Conducted by Company on Environmental Management Performance at PT X

There are several environmental innovations that have been done by PT X over the last two years. The assessment of the achievement of environmental performance by PT X management has been limited to the awards and also the absence of complaints from the public (Respondent 2, 2018). This is because the environmental innovations made by PT X are not based on the weaknesses, or shortcomings, arising from the environmental strategy created, but only based on existing legislation.

The management of PT X considers that by obtaining the Blue Proper criterion from the Ministry of Environment, PT $\mathrm{X}$ has fulfilled all the requirements on environmental management required by the government in accordance with prevailing legislation and regulations, so that the stakeholders are not affected by how much actual environment performance has been achieved by the company (Respondent 1, 2018). This causes the company's environmental performance to fall short of the benchmark achievement for environmental performance in terms of being right for environmental innovation. Thus, PT X considers that environmental innovation has been in accordance with the needs and doing well due to its achievement of good environmental performance through environmental awards obtained by the company (Respondent 1, 2018).

Based on that, to conduct a current assessment of the achievement of good environmental performance by companies in Indonesia is mostly assessed from the environmental awards obtained by companies from the government or the Ministry of the Environment because there has been no other better and more detailed assessment of maximum achievement of environmental performance by companies in Indonesia. Because firms with higher proper blue, gold, and green ratings indicate that the company's environmental performance is also improving. So that the company that managed to get the award is considered to have made effort to control environmental problems and has also undertaken environmental management in the community for having done things that are required as a requirement to get this award. This achievement is the most convincing test that the management of PT X has achieved good environmental performance through the environmental innovation of it creates.

\section{CONCLUSION}

\section{A. Summary of Findings}

Up until now, PT X has not focused on internal factors in the company, i.e., human resources in project management which do not yet fully know the importance of human resources as a component that influences the strategic management of company. This reality is not in accordance with the previous research conducted by Dunford, et al. [23], suggesting that strategic management is influenced by the existence of human resources that have value and important functions in the company to optimize the company's competitive advantage. Accordingly, PT X needs to use RBV theory to understand the importance of human resources because most of the environmental performance and costs incurred in PT X are calculated and assessed based on every 
project done and human resources thus become an important element in formulating good and qualified EMSyst in order to ensure that the projects carried out can run well and mature and in accordance with the needs of the company. PT $\mathrm{X}$ has not made human resources one of its competitive advantages so that its personnel do not have a deep understanding of its management system, calculation and environmental audit to assist indecision making and implementation of the EMSyst that has been enacted so far. The first thing that can be done by PT $\mathrm{X}$ to improve its EMSyst is through the existing human resources it has by utilizing RBV theory.

PT X has been implementing EMSyst in accordance with ISO 14001, but that implementation only incorporates basic components such as environmental aspects, provisions of existing regulation, making reviews and setting targets, and formulating an environmental program in accordance with needs and responsibilities of the company. PT X does not use environmental strategy planning by implementing EMA as well as EMR. So, the environmental strategy is not maximal and does not reflect the actual needs and targets of the company. This is in line with what De Beer and Friend [15] explained: EMA is a tool for better understanding and ease of measuring environmental problems. In the implementation of the environmental strategy the shortcomings and weaknesses were often the cause of the emergence of new environmental problems. This outcome is due to the lack of maximum calculation in the creation of environmental strategies. Environmental innovations taken as the main act of solving environmental problems are not based on the weaknesses and shortcomings of existing environmental strategies, but rather to show that environmental innovations are made because PT $\mathrm{X}$ cares about environmental sustainability. Environmental innovations made by the company are not fully able to resolve the environmental problems that occur.

PT X has been guided by EMSyst by ISO 14001 which has simplified and assist the company in overcoming all activities related to the environment. However, to improve the implementation of EMSyst by the company, PT X needs to identify and classify the environmental costs separately from each of the existing divisions and factories to be recorded into one environmental cost account. That way, PT $X$ can easily know the number of environmental costs obtained and the benefits obtained from the costs incurred, in order to maximize its environmental strategy and implementation of such schemes that can produce environmental innovation in accordance with the required regulations. In addition, it may also achieve the maximum environmental performance for the company yearly. By improving the existing EMSyst using the application of EMA and EMR, then PT X may better know the environmental problems that occur in or due to the company. Thus, no more environmental problems will arise without management's knowledge, and PT X will be able to better improve its environmental performance each year.

\section{B. Limitations of the Study}

This study has several limitations and shortcomings, namely limited time and limited locations that could be visited in the research area due to the strict system in the company and the existing factories. Difficult access to financial statements and also manual systems that are still applied in the company to make the data obtained only useful for a single period. Data obtained only came from one division only because of the limitations of permits granted by the company. Finally, analyzing the environmental costs of non-financial indicators from environmental benefits as well as environmental costs were limited, so that the results obtained cannot reflect the full environmental costs because they do not include the value of non-financial indicators that exist in the environmental benefits and costs.

\section{Suggestion for Further Study}

A follow-up research suggestion would be to examine all the divisions and factories in PT X and to find out all the environmental cost data contained therein to be identified and grouped according to the environmental cost component. In addition, an environmental cost analysis of non-financial indicators related to environmental benefits should be conducted, too. Thus, environmental costs may be judged financially to be able to know for sure how much of the costs received are reflected in benefits received by the company, considering the environmental costs incurred so far. Other research methods, e.g., a mixed method may be used to enrich the research results.

\section{ACKNOWLEDGMENT}

We hereby would like to acknowledge the assistance provided by University of Indonesia's Office of Research and Innovation Product Management (KPPRI UI) or Kantor Pengelolaan Produk Riset dan Inovasi Universitas Indonesia (KPPRI UI) on their generosity to provide free of charge proof reading services.

\section{REFERENCES}

[1] Masanet-Llodra, M. (2006). Environmental management accounting: A case study research on innovative strategy. Journal of Business Ethics, 68(4), 393-408.

[2] Ferreira, A., \& Otley, D. (2009). The design and use of performance management systems: an extended framework for analysis. Management Accounting Research, 20(4), 263-282.

[3] Aragón-Correa, J. A., Hurtado-Torres, N., Sharma, S., \& GarcíaMorales, V. J. (2008). Environmental strategy and performance in small firms: A resource-based perspective. Journal of Environmental Management, 86, 88-103.

[4] Hart, S. (1995). A natural resource based view of the firm. Academy of Management Review, 20(4), 986-1014.

[5] The Environmental Accounting Guidelines Japan. (2005). Ministry of the Environment. [Online]. Available from :http://www.env.go.jp/en/ policy/ssee/eag05.pdf . [Accessed 24th February 2018]

[6] Tempo.co. (2004). Residents Complained about PT Krakatau Steel's Waste. [Online]. Available from: https://nasional.tempo.co/read/ 45684/warga-keluhkan-limbah-pt-krakatau-steel. [Accessed 24th February 2018].

[7] Fakta, B. (2018). Enacting air pollution production steel waste dust pollution in ciwandan. [Online] Available from: http://faktabanten. co.id/meresahkan-polusi-debu-2-limbah-produksi-baja-cemari-udaradi-ciwandan/ . [Accessed 22th February 2018].

[8] Satelitnews. (2014) Ciwandan was again bombarded with factory dust. [Online]. Available from: http://satelitnews.co.id/2014/05/20/ ciwandan-kembali-dihujani-debu-pabrik/ [Accessed 24th February 2018].

[9] Khanna, D. R., Bhutiani R., \& Gagan M. (2009). Environmental management system. J. Comp. Toxicol. Physiol. 6(I), 010-017.

[10] Mezinska, I., \& Santa, S. (2015). Emerging horizons of environmental management in food sector companies. Journal of Social and Behavioral Sciences, 213, 527-532.

[11] Banerjee, S. B., Iyer, E. S., \& Kashyap, R. K. (2003) Corporate environmentalism: Antecedents and influence of industry type. Journal of Marketing, 67(2), 106-122. 
[12] Ochsner, M. (1998) Pollution prevention: An overview of regulatory incentives and barriers. NYU Environmental Law Journal, 6(3), 586617.

[13] Hoffman, A. J. (1999). Institutional evolution and change: Environmentalism and the U.S. chemical industry. Academy of Management Journal, 42, 351.

[14] Cater, T., Janez P., \& Barbara Č. (2009). Environmental strategies and their motives and results in slovenian business practice. Journal of Economic and Business Review, 11, 55-74.

[15] De Beer, P., \& Friend, F. (2006). Environmental accounting: A management tool for enhancing corporate environmental and economic performance. Journal of Ecological Economics, 58, 548600.

[16] Jasch, C. (2003). The use of environmental management accounting (EMA) for identifying environmental costs. Journal of Cleaner Production, 11, 667-676.

[17] Duma, H., İçerli, M. Y., Yücenurșen, M., \& Apak, İ. (2013). Environmental cost management within the sustainable business. Journal of Science and Technology, 3(2).

[18] Cainelli, G, Mazzanti, M., \& Montresor, S. (2012). Environmental innovations, local networks and internazionalitation. Industry and Innovation, 19, 697-734.

[19] Nadkarni, S., \& Nakarayanan, V. K. (2007). Strategic schemas, strategic flexibility, and firm performance: The moderating role of industry clock speed. Strategic Management Journal, 28, 243-270.
[20] Schultze, W., \& Trommer, R. (2012). The concept of environmental performance and its measurement in empirical studies. Journal of Management Control, 22, 375

[21] Moneva, J. M., \& Ortas, E. (2010). Corporate environmental and financial performance: A multivariate approach. Industrial Management \& Data Systems, 110(2), 193-210.

[22] Killen, C., Jugdev, K., Drouin, N., \& Petit, Y. (2012). Advancing project and portfolio management research: Applying strategic management theories. International Journal of Project Management, 30(5), 525-538.

[23] Dunford, B. B, Snell, S. A., \& Wright, P. M. (2001). Human resources and the resource based view of the firm (CAHRS Working Paper \#01-03). Ithaca NY: Cornell University, School of Industrial and Labor Relations, Center for Advanced Human Resource Studies.

[24] IFAC. (2005) International Guidance Document of EMA, IFAC, Laxenburg, available at: www.ifac.org

[25] Cingoz, A., \& Akdogan, A.A.. (2013) Strategic flexibility, environmental dynamism, and innovation performance: An empirical study. Journal of Social and Behavioral Sciences, 99, 582-589.

[26] Government of The Republic of Indonesia. (2010). Government Regulation Number 71 of 2010 Concerning Government Accounting Standard. Jakarta: Government of Indonesia. Mauro, P. (1995). Corruption and growth. The Quarterly Journal of Economics, 110(3), 681-712. 